\title{
Health education workshops with children in the context of COVID-19 pandemic
}

\author{
Oficinas de educação em saúde com crianças no contexto de pandemia da COVID-19
}

Taller de educación en salud con niños en el contexto de pandemia de COVID-19

Renata de Moura Bubadué'
ORCID: 0000-0001-8121-1069
Carla Chiste Tomazoli dos Santos'
ORCID: 0000-0001-7671-2264
Ismael Ferreira'
ORCID: 0000-0003-3717-3362
'Faculdade de Ciências e Educação Sena Aires.
Valparaíso de Goiás, Goiás, Brazil.
How to cite this article:
pundemic. Rev Bras Enferm. 2020;73(Suppl 2):e20200593.
workshops with children in the context of COVID19
doi: http:/dx.doi.org/10.1590/0034-7167-2020-0593
Corresponding author:
Renata de Moura Bubadué

\begin{abstract}
Objective: Describe the experience of extension activities in the prevention of COVID-19 with children from public school system. Methods: Experience report of critical and reflexive approach on the extension experience of the project "Healthcare at School" (Atenção à Saúde na Escola), in the COVID-19 pandemic context, in a countryside town in the State of Goias, in March 2020. Results: It is carried out five hand sanitizing workshops as a prevention for COVID-19 with 57 children from 2 to 5 years old in the State of Goias. Final considerations: The playful approach in a low-cost workshop format was a strategy to meet an emergency requirement of the Community in the beginning of the COVID-19 pandemic.
\end{abstract}

Descriptors: Pandemics; Children; Public Health; Health Education; Pediatric Nursing.

\section{RESUMO}

Objetivo: Descrever a experiência de atividades extensionistas de prevenção da COVID-19 com crianças da rede pública de ensino. Métodos: Relato de experiência de abordagem crítica e reflexiva sobre a vivência extensionista no projeto "Atenção à Saúde na Escola", no contexto pandêmico da COVID-19, em uma cidade do interior de Goiás, em março de 2020. Resultados: Realizaram-se cinco oficinas de higienização das mãos como prevenção da COVID-19 com 57 crianças de 2 a 5 anos em Goiás. Considerações finais: A abordagem lúdica na forma de oficinas de baixo custo foi uma estratégia para atender a uma demanda emergencial da comunidade no início da pandemia da COVID-19.

Descritores: Pandemias; Criança; Saúde Pública; Educação em Saúde; Enfermagem Pediátrica.

\section{RESUMEN}

Objetivo: Describir la experiencia de actividades extensionistas de prevención a la COVID-19 con niños de la red pública de enseñanza. Métodos: Relato de experiencia de abordaje crítico y reflexivo sobre la vivencia extensionista en el proyecto "Atención a la Salud en la Escuela", en el contexto de la pandemia de COVID-19, en una ciudad del interior de Goiás, en marzo de 2020. Resultados: Realizaron cinco talleres de higienización de las manos como prevención a la COVID-19 con 57 niños de 2 a 5 años en Goiás. Consideraciones finales: El abordaje lúdico en la forma de talleres de bajo costo ha sido una estrategia para atender a una demanda de emergencia de la comunidad en el inicio de la pandemia de COVID-19. Descriptores: Pandemias; Niño; Salud Pública; Educación en Salud; Enfermería Pediátrica. 


\section{INTRODUCTION}

On March 11, 2020, World Health Organization decreed that the world faced a pandemic caused by the COVID-19. First time defined in December 2019, in China, COVID-19 is an infectious disease caused by the coronavirus of severe acute respiratory syndrome 2 (SARS-CoV-2), and it is present in 114 countries $^{(1)}$.

With the growing of exponential cases, it is registered more than 25 million of notifications and 22,970.240 deaths in the world until August 22, 2020. In Brazil, there are 3,582.362 cases, with 114,250 deaths registered in all age groups. Data about child population from 1 to 5 years old is restricted to those hospitalized by SARS-CoV-2. From the 18,267 notifications of SARS, 1,860 had the COVID-19 diagnosis confirmed, and 123 died $^{(2)}$.

Studies indicate that the prognosis of the disease in the child population is favorable when compared to adults. It shows that the most part of children does not show symptoms originated by the infection of the new coronavirus. Thus, they may be considered virus vectors, occupying a social space that expose adults around them to the infection and to the course of the disease in a more meaningful way ${ }^{(3-5)}$. However, it is important to highlight that the children are also vulnerable to the disease and its aggravations.

In this sense, when we mention studies showing that children may be considered virus vectors, we do not intend to blame them for any possible infection. We aim to emphasize the importance to work with this population for the prevention of COVID-19, once we recognize children population while moral agent. That is, children are able to act deliberately, speak for themselves and reflect on their interaction with the world. This means that they have their own world views and ways of interacting, with language being expressed in a variety of ways and not just by speech ${ }^{(6)}$.

In the face of it, we point out that school is a children's socialization space, where they can interact to each other to build knowledge. Children between 2 and 5 years of age are in the process of improving communication and motor skills ${ }^{(7)}$, and are encouraged to introduce concrete health education topics, such as hand hygiene - one of the main measures for the prevention of COVID-19 with $55 \%{ }^{(8-10)}$ effectiveness in health education strategies.

\section{OBJECTIVE}

To report the experience of teachers and undergraduate students of health field in conducting hand sanitizing workshops in order to prevent the COVID-19 with children at school environment.

\section{METHODS}

\section{Methodological procedures}

Experience report ${ }^{(11)}$ of five workshops on hand sanitizing developed with 57 children between 2 and 5 years old in March 2020, which stages were described in the results.

The playful workshop was chosen because it offers a space for the build of knowledge with children, having the entertainment as a methodological and strategic resource for communication with this population. Through play and imagination, the child has the possibility to think about specific topics in a clear and atraumatic way ${ }^{(12-13)}$.
Workshops were conducted by 15 undergraduates in the health field (Physiotherapy and Nursing), supervised by coordinating teachers of the Extension project "Healthcare at School" (Atenção à Saúde na Escola), which objectives are: develop actions of prevention, promotion and health monitoring of children and adolescents enrolled in the public school system; b) disseminate scientific knowledge of health among the children and youth population; and c) offer a teaching and learning space for undergraduate students of the educational institution to which they are linked.

This project is carried out in accord with public health issues relevant to the population for which it is intended. The theme COVID-19 emerged: a) from the spontaneous demand of school teachers, who contact the coordination of the project in order to prepare the workshops, and the coordinators conducted the planning and execution activities together with the undergraduate students; and b) from the vulnerability scenario in which the school is localized.

\section{Activities Scenario}

The workshops were held at an integrated education center in a municipality in the countryside of the State of Goias, which has 357 enrolled children between 0 and 5 years of age, where it is offered classes from Nursery I to Kindergarten II.

The pedagogical project involves playful teaching activities that stimulates musicality, psychomotricity, and the biopsychosocial development, as well as the practice of sports and water recreation in a structure that offers a playroom and a video library. The educational center operates from a perspective of valuing the individuality of the child and how it can contribute to the group in which it is inserted; in this line, it encourages the discovery of new talents and the development of skills for inclusion and social integration.

The municipality of the Center has approximately population of 168,468 inhabitants, according to the Brazilian Institute of Geography and Statistics (IBGE), with COVID-19 incidence of 93.2 and the mortality rate 1.8 per 100 thousand inhabitants. To date, there are no reports of cases in children in the region.

\section{RESULTS}

The planning and execution stage of the workshops had a brief period, which contributed to coordination's insecurity and anxiety of the referred extension project. The demand arouse from school teachers in the morning of March 16, 2020; but, despite we were excited with the possibility to disseminate knowledge among children on a topic so relevant to the present public health, there was an imminent complicating.

\section{Washing Hands Workshop Planning}

That morning, the emergency planning for the workshops began, which stages were: 1) identification of target audience regarding its quantitative (number of children) and its qualitative (age and human development staging); 2) analysis of material, structural and human resources available for the activity; 3 ) choice of scientific contents to be approached and the pedagogic strategy to be used. 
In the first and second stages, a message exchange application was used for the project coordination to collect data regarding the target population, the material and structural resources of the teaching institution in which the activity would be developed with the teachers that identified the demand. And, with the same means of communication, students from the $5^{\text {th }}$ to the $7^{\text {th }}$ period of the Physiotherapy course and the $3^{\text {rd }}$ semester of Nursing were contacted to compose the human resources of the project, because extension can be a way of growth and learning for students.

Regarding material resources, it was used alcohol gel 70\%, a pot of ink gouache type, sheets of paper towel, and liquid soap. In relation to structural resource, the school had classrooms and community sinks adapted to the children's height. Human resources were composed of 15 undergraduate students.

In the third stage, it was determined that the contents to be addressed would be: virus; infection; prevention as social responsibility to others; and hand sanitizing. Also, it was established that the approach would be problematizing, focused in the pupil following the precepts of Freire's liberating education ${ }^{(14)}$ - and adapted to child population and their development staging, which requires interaction with materials and academics, in order to provide concreteness to the discussed information.

To give playfulness to the approach, the 15 undergraduate students were advised to wear childish motifs clothes, such as superheroes, cartoons characters and princesses. The name of these characters would be the aliases in the playful communication with the child.

\section{Functionality of the Workshops}

Workshops had 5 stages

\section{STAGE 1) Establishing agreements with school representatives}

Firstly, the team was welcomed by the school's coordinator and director, which presented the material and structural resources available for the workshops. Subsequently, it was agreed regarding the schedule, classes available for the activity, and order of execution, in order to avoid interruption in the planned didacticpedagogical activities, meals and/or children's recreation times. Workshops started with classes containing children of 2 and 3 years old, following classes with children of 4 and 5 years old.

\section{STAGE 2) Presentation and creation of the group greeting}

Characterized as cartoon characters, the undergraduate students presented themselves with their aliases, and invited children to create a group greeting, which was similar to the superheroes'.

\section{STAGE 3) Identification of the group knowledge}

In this stage, the undergraduate students talked to the children, asked for the importance of washing hands and new ways of greeting, agreeing that the greeting created at the beginning would be the way of interaction with each other during the pandemic period. Children from 4 to 5 years old had a sophisticated linguistic and cognitive ability, making the approach more dialogued than that of children aged 2 to 3 years old.

\section{STAGE 4) Hand sanitizing technique}

Using gouache ink, soap, sink, towels, and alcohol 70\%, undergraduate students presented hand sanitizing technique to the children. They started placing a little gouache ink in the children's hands, asking them to imagine that that was the virus. Subsequently, they demonstrated the movements of the technique, guiding them about the importance of removing all the virus off the hand. Lastly, they used alcohol $70 \%$ as a protection resource after the cleaning, explaining that it may be used when there is no possibility to hand sanitizing with water and soap.

\section{STAGE 5) Knowledge reinforcement and farewell}

In the last stage, undergraduate students reinforced the importance of children teach their colleagues and adults about their learning, encouraging them on their role of knowledge multipliers among their peers and families. In the end, children said goodbye with the greeting created, and they were reinforced about the importance of maintaining study habits at home.

\section{DISCUSSION}

The workshop was held on the last day of classroom activities, since a municipal decree ${ }^{(15)}$ was emitted to meet the COVID-19 prevention requirements, recommended by the country's Ministry of Health.

Therefore, the coordination of the project met to deliberate on the decision to meet the school's demand. Considering the ethic-professional responsibility ${ }^{(16)}$ of health professionals and health professors in the pandemic context, the social commitment in the extension study in the contribution to the transformation of the local reality ${ }^{(17)}$, and the institutional values that appreciate the graduation of critical and reflective students capable of acting in different scenarios, we chose to face the challenge.

Studies indicate that student's participation in university extension activities promote the development of communication and dialogue skills with the population, being a valuable tool in the mediation of scientific information in several contexts, including the school ${ }^{(18-19)}$.

In addition, the inclusion of undergraduate students in an emerging demand from the community exposes them to a situation close to the daily routine of professional practice, as advance planning is not possible in all situations. However, as undergraduate health professionals, they could understand their ethic responsibility with population, which looks for knowledge and information in education and health promotion spaces.

In this sense, the importance of a university extension stands out so that the student build the professional identity in informal spaces, expanding the vision of health, thinking about the areas of activity available in the society and identifying the importance of ethical positioning before the demands that were not planned, although important for the Single Health System (SUS) user.

To carry out the workshops, the academics were instructed to wear colorful clothing with cartoon and comic characters, in order 
to add playfulness to the approach. Studies show that in pediatrics, the use of colorful clothes instead of white smock favors the bond between children and health professionals, as it transmits information of fun and not seriousness during health actions ${ }^{(20)}$.

It is important to highlight that, although the workshops stages are similar, the language and information varied according to the stage of development in which the children were. Studies show that the physic, social, motor, linguistic, and cognitive capacity of children between 2 and 5 years old expressly vary ${ }^{(21)}$.

Growth and development milestones are achieved in an exponential way. Physically, the bone, articular, and muscle structures of a child of 2 years of age offer less balance and sophistication than a child of 5 years of age, which reflects in her motor ability. Social development follows the emotional, which aptitude of recognizing and controlling their emotions acquired over the years modulates their peer relationships. Regarding the difference in the linguistic and cognitive ability is in the number of words that each age group stores and verbalize in dialogues. The vocabulary repertoire of a 2-year-old child is, on average, 50 words, while that of a 5-year-old child is thousands of words, reflecting on the ability to tell stories ${ }^{(22)}$.

The first stage corresponded to the individual presentation and children's awareness for the activity. With children from 2 to 3 years old, the concrete actions prevailed in the second stage, when the undergraduate students invited them to play with ink and paint the hands. Subsequently, children were directed to a sink to learn the washing hands technique and its importance. In this age group, the concrete provided by playful activities helps the child to materialize his actions for the abstraction of thought, capable of reproducing actions ${ }^{(23-24)}$.

\section{Study Limitations and Contributions in the Area}

A limitation of the report was the one-sidedness of the information, once the experiences of coordinating teachers and undergraduate students were presented, instead of the children's, who participated in the workshops. In addition, the impacts in the activity in the child's life and in the prevention of the COVID-19 were not evaluated.

\section{FINAL CONSIDERATIONS}

Health education by means of the technical workshop of hand sanitizing was a low-cost strategy, which implications can have significant sanitary impacts in the prevention of COVID-19, in the face of the emergency pandemic context.

Extension activities can contribute for the development of Physiotherapy and Nursing undergraduate students in the acquisition of abilities and tools to take actions in the prevention of COVID-19 with children. The teamwork can help in the implementation of action that value and recognize the child potential to multiply information for adults and among their peers. Exploring the playful and the workshop approach help the child in creating a bond between knowing and making, leading him/her to give concreteness to concepts related to prevention and care.

The health professionals, including pediatric nurses, have ethical-professional responsibility for public health actions in all age groups. Therefore, the activity was an opportunity for learning and exchange for undergraduate students, teachers and children through the situation that presented itself.

Therefore, recognizing children as relevant people in health actions can expand the strategic effectiveness of public health in facing epidemics, incorporating school as a space for health promotion.

\section{ACKNOWLEDGMENTS}

We would like to thank the children and teachers of the participating institution for building knowledge.

\section{REFERENCES}

1. World Health Organization. WHO Director-General's opening remarks at the media briefing on COVID-19 [Internet]. 2020 [cited 2020 Apr 17]. Available from https://www.who.int/dg/speeches/detail/ who-director-general-s-opening-remarks-at-the-media-briefing-on-covid-19---11-march-2020

2. Ministério da Saúde (BR). Boletim Epidemiológico Especial n. 28. Doença pelo Coronavírus COVID-19. Semana Epidemiológica 34 (16 a 22/08) [Internet]. 2020 [cited 2020 Sep 1]. Available from https://saude.gov.br/images/pdf/2020/August/27/Boletim-epidemiologicoCOVID-28-FINAL-COE.pdf

3. Lu Q, Yuan S. Coronavirus disease (COVID-19) and neonate: what neonatologists need to know. J Med Virology. 2020. doi: 10.1002/jmv.25740

4. Ludvigsson JF. Systematic review of COVID-19 in children shows milder cases and a better prognosis than adults. Acta Paediatr. 2020;109(6):1088-95. doi:10.1111/apa.15270

5. Xia W, Shao J, Guo Y, Peng X, Li Z, Hu D. Clinical and CT features in pediatric patients with COVID-19 infection: different points from adults. Pediatr Pulmonol. 2020;55(5):1169-74. doi:10.1002/ppul.24718

6. Montreuil M, Carnevale FA. A concept analysis of children's agency within the health literature. J Child Health Care. 2016;20(4):503-11. doi:10.1177/1367493515620914

7. Fonseca EMGO. Desenvolvimento Normal de 1 a 5 anos. Rev Pediatr SOPERJ [Internet]. 2011 [cited 2020 Sep 1];4(8). http:// revistadepediatriasoperj.org.br/audiencia_pdf.asp?aid2=551\&nomeArquivo=v12n1s1a01.pdf

8. Chen X, Ran L, Liu Q, Hu Q, Du X, Tan X. Hand hygiene, mask-wearing behaviors and its associated factors during the COVID-19 Epidemic: a crosssectional study among primary school students in Wuhan, China. Int J Environ Res Public Health. 2020;17(8):2893. doi:10.3390/ijerph17082893 
9. Thampi N, Longtin Y, Peters A, Pittet D, Overy K. It's in our hands: a rapid, international initiative to translate a hand hygiene song during the COVID-19. J Hosp Infect. 2020;S0195-6701(20)30234-6. doi:10.1016/j.jhin.2020.05.003

10. Wang Y, Zhou CC, Shu R, Zou J. Oral Health Management of Children during the Epidemic Period of Coronavirus Disease 2019. Sichuan Da Xue Xue Bao Yi Xue Ban. 2020;51(2):151-154. doi: 10.12182/20200360101

11. Marconi MA, Lakatos EM. Metodologia do Trabalho Científico. 8. ed. São Paulo: Atlas; 2017. 256 p.

12. Miranda S. Oficina de Ludicidade na Escola. Papirus Editora: Campinas; 2013. 128 p.

13. Jurdi APS, Silva CCB, Liberman F. Inventários das brincadeiras e do brincar: ativando uma memória dos afetos. Interface (Botucatu). 2018;22(65):603-8. doi: 10.1590/1807-57622016.0978

14. Kohan WO. Paulo Freire: other childhoods for childhood. Educ Rev. 201834:e199059. 2018. doi:10.1590/0102-4698x199059

15. Governo Municipal de Valparaíso de Goiás. Decreto 149 de 16 de Março de 2020. Decreta a suspensão das atividades educacionais como medida de combate à pandemia pela infecção pelo novo COVID-19 e dá outras providências [Internet]. 2020[cited 2020 May 28]. Available from https://acessoainformacao.valparaisodegoias.go.gov.br/legislacao/decretos

16. Carnevale F. Ethical Considerations in Pediatric Nursing. Rev Soc Bras Enferm Pediatra [Internet]. 2012. [cited 2020 May 28];12(1):37-47. Available from https://sobep.org.br/revista/images/stories/pdf-revista/vol12-n1/v.12_n.1-art4.pesq-consideracoes-eticas-enfermagem.pdf

17. Teixeira CM, Carvalho AS, Martins PS. Responsibility: From its conceptual foundations to its practical application in intensive care units. Acta Bioeth. 2018;24(1):47-56. doi: 10.4067/S1726-569X2018000100047

18. Castillo J, Paleo C, Rivero Borges A. Curricularización de la extensión en la FCEA 2012-2017. InterCambios. 2019;6(2):79-91. doi: 10.29156/ inter.6.2.9

19. Gomes AM, Santos MS, Finger D, Zanittini A, Franceschi EV, Souza JB, et al. Refletindo sobre as práticas de educação em saúde com crianças e adolescentes no espaço escolar. Avaliação: Revista da Avaliação da Educação Superior (Campinas) [Internet]. 2018 [cited 2020 Sep 1];11(3):332-41. Available from: https://revistas2.uepg.br/index.php/conexao/article/view/7592

20. Oliveira CT, Santos AS, Dias ACG. Percepções de Estudantes Universitários sobre a Realização de Atividades Extracurriculares na Graduação. Psicol Ciên Prof. 2016;36(4):864-76. doi: 10.1590/1982-3703003052015

21. Jurko Jr A, Minarik M, Jurko T, Tonhajzerova I. White coat hypertension in pediatrics. Ital J Pediatr. 2016 [cited 2020 May 28];42:4. doi: $10.1186 / \mathrm{s} 13052-016-0213-3$

22. Syadar SF, Zarifian T, Modarresi Y, Zahedi MS, Ebrahimipour M, Biglarian A. Kurdish Speech Test: A validation study for children aged 3-5 years. Int J Pediatr Otorhinolaryngol. 2019;117:61-66. doi: 10.1016/j.ijporl.2018.10.009

23. Ahun MN, Aboud FE, Aryeetey R, Colecraft E, Marquis GS. Child development in rural Ghana: Associations between cognitive/language milestones and indicators of nutrition and stimulation of children under two years of age. Can J Public Health. 2018;108(5-6):e578-e585. doi: $10.17269 /$ cjph. 108.5875

24. Sarmento MJ. Uma agenda crítica para os estudos da criança. Curr Sem Front [Internet]. 2015 [cited 2020 May 28]:15(1):31-49. Available from http://www.curriculosemfronteiras.org/vol15iss1articles/sarmento.pdf 